ИЗВЕСТИЯ АКАДЕМИИ НАУК ЭСТОНСКОИ ССР. ТОМ 27 ХимИЯ. 1978, № 4

\title{
К ХАРАКТЕРИСТИКЕ ГРАПТОЛИТОВОГО СЛАНЦА ВОРМСИСКОГО ГОРИЗОНТА ЮЖНОЙ ЭСТОНИИ
}

Возрастающая потребность в отыскании новых энергетических ресурсов обусловливает необходимость учета даже некондиционных запасов горючих ископаемых, - например, диктионемового аргиллита. Широкому кругу геохимиков неизвестно, что в Эстонии имеются залежи и других сланцев, подобных диктионемовым.

В начале позднего ордовика в северной части Балтийской синеклизы, несколько южнее современного Рижского залива, отлагались карбонатные осадки, в разрезе чередующиеся с граптолитовыми илами, обогащенными органическим (сапропелевым) веществом. Содержание керогена в некоторых породах верхнего ордовика достигает $20 \%$, что ставит их в один ряд с горючими сланцами [1].

В ходе бурения регионального картирования в южной Эстонии (скв. Карула, Валга, Отепя) в отложениях позднего ордовика на глубине 370 м были вскрыты богатые органикой черные сланцы, которые по возрасту были отнесены к свите Фяка вормсиского горизонта [2].

Сланец представлен черновато-серым глинистым аргиллитом, содержащим остатки граптолитов Tetraspis. Формирование верхнеордовикских граптолитовых сланцев вормсиского горизонта непосредственно связано с западноевропейской геосинклинальной зоной, и они представляют собой краевую фацию последнего [ [2]. Тетрасписовые сланцы формировались в центральной части бассейна в завершающей стадии верхнеордовикской трансгрессии. На это указывает наличие следов илоедов в верхней части горизонта, отсутствйе прослоек алеврита и коричневые известняки регрессивной фазы в следующем пиргуском горизонте. Степень превращенности тетрасписового сланца соответствует поздней диагенетической стадии $\mathrm{Б}_{1-2}$.

Сланец характеризуется значительным содержанием тонкодисперсного органического вещества, которое равномерно и тонко рассеяно в виде многочисленных точек и сгущений черно-коричневого цвета. В сланце в большом количестве присутствуют зерна кальцита и рассеянный пирит, местами образующий пятна $(0,5-0,8$ мм). На поверхности зерен кальцита наблюдаются тонкие коричневые пленки органическото вещества. Максимальная мощность сланца в скважине Карула - 3 м. В сторону Валга, Отепя и Пылва сланец выклинивается. В скважине Валга сланец присутствует в виде тонких прослоек от 0,5 cм до 15 cm, а в Пылва - в виде включений.

Характеристика исходното сланца (на аналитическую пробу, вес. \%) : влага $W^{a} 3,4$; зола $\mathrm{A}^{\mathrm{c}} 79,0$; углекислота карбонатов $\mathrm{CO}_{2} 5,8$; нераство- 


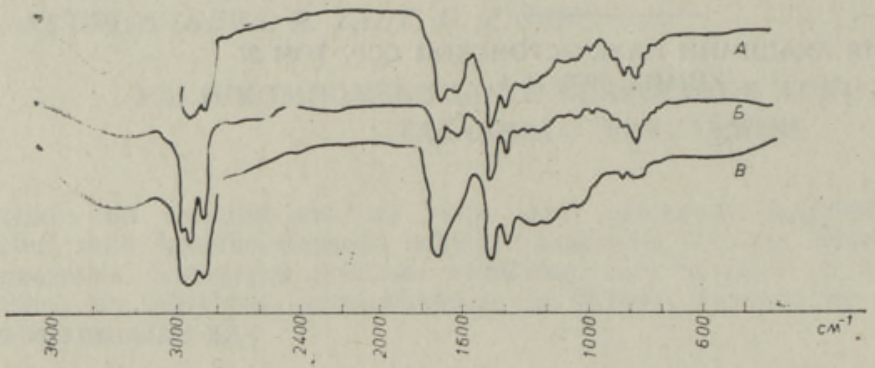

Рис. 1. Инфракрасные спектры смолы полукоксования исходного $(A)$ и дебитуминированного (Б) сланца и битумонда $(C)$.

римый в соляной кислоте остаток 90,0; условная органическая масса 15,$2 ; \mathrm{C}_{\text {opr. }} 10,9 ;$ гуминовые кислоты 0,09 .

Выделение растворимой части фракций органического вещества производилось по принятой в геолого-битуминологических исследованиях методике [3], включающей извлечение битумоида $A$ экстракцией породы хлороформом в аппарате Сокслета, последуюшую обработку породы соляной кислотой и выделение из нее битумоида $C$ спиртобензольной смесью. С целью характеристики нерастворимой части органического вещества дебитуминированный сланец подвергли термической деструкции по ГОСТ 3168-66. Разделение битумоида и смол полукоксования на групповые компоненты (дальнейшее исследование которых проводилось

Сравнительная характеристика битумоидов и смол полукоксования горючих сланцев Эстонской ССР

\begin{tabular}{|c|c|c|c|c|c|c|c|}
\hline \multirow[b]{3}{*}{ Показатели } & \multicolumn{7}{|c|}{ Сланец } \\
\hline & \multicolumn{2}{|c|}{ Тетрасписовый } & \multicolumn{3}{|c|}{ Кукерсит } & \multicolumn{2}{|c|}{ Диктионемовый } \\
\hline & $\begin{array}{l}\text { Битумо- } \\
\text { ид } A \\
\text { (хлоро- } \\
\text { формен- } \\
\text { ный) }\end{array}$ & $\begin{array}{c}\text { Битумо- } \\
\text { ид } C \\
\text { (спирто- } \\
\text { бензоль- } \\
\text { ный) }\end{array}$ & $\begin{array}{c}\text { Смола } \\
\text { полу- } \\
\text { коксо- } \\
\text { вания }\end{array}$ & $\begin{array}{c}\text { Битумо- } \\
\text { ид C } \\
\text { (спирто- } \\
\text { бензоль- } \\
\text { ный)* }\end{array}$ & $\begin{array}{c}\text { Смола } \\
\text { полу- } \\
\text { коксо- } \\
\text { вания ** }\end{array}$ & $\begin{array}{l}\text { Битумо- } \\
\text { ид } A \\
\text { (спирто- } \\
\text { бензоль- } \\
\text { ный)**** }\end{array}$ & $\begin{array}{l}\text { Смола } \\
\text { полу- } \\
\text { коксова- } \\
\text { ния ***** }\end{array}$ \\
\hline
\end{tabular}

Элементный состав, вес. \%:

углерод
водород
гетероатомы
$(\mathrm{H} / \mathrm{C})$ ат м.

$\begin{array}{ccccccc}77,1 & 66,6 & 83,9 & 78,2 & 82,6 & - & 84,1 \\ 10,2 & 8,0 & 10,1 & 10,6 & 10,5 & - & 8,5 \\ 12,8 & 25,4 & 6,0 & 11,2 & 6,9 & - & 7,4 \\ 1,59 & 1,44 & 1,44 & 1,63 & 1,53 & - & 1,21\end{array}$

Групповой химический состав, вес. $\%$ :

неароматические углеводороды одноядерные ароматические углеводороды конденсированные ароматические углеводороды гетероатомные соединения

* Слой $B$, битумоид выделила и проанализировала Р. В. Пайс: ** валовая проба $\left.{ }^{6}\right]$; *** участок Маарду $\left.{ }^{7}\right]$; **** элементный состав - участок Маарду ${ }^{8}{ }^{8}$, групповой анализ смолы (участок Тоолсе) проводила Ю. Т. Риккен. 


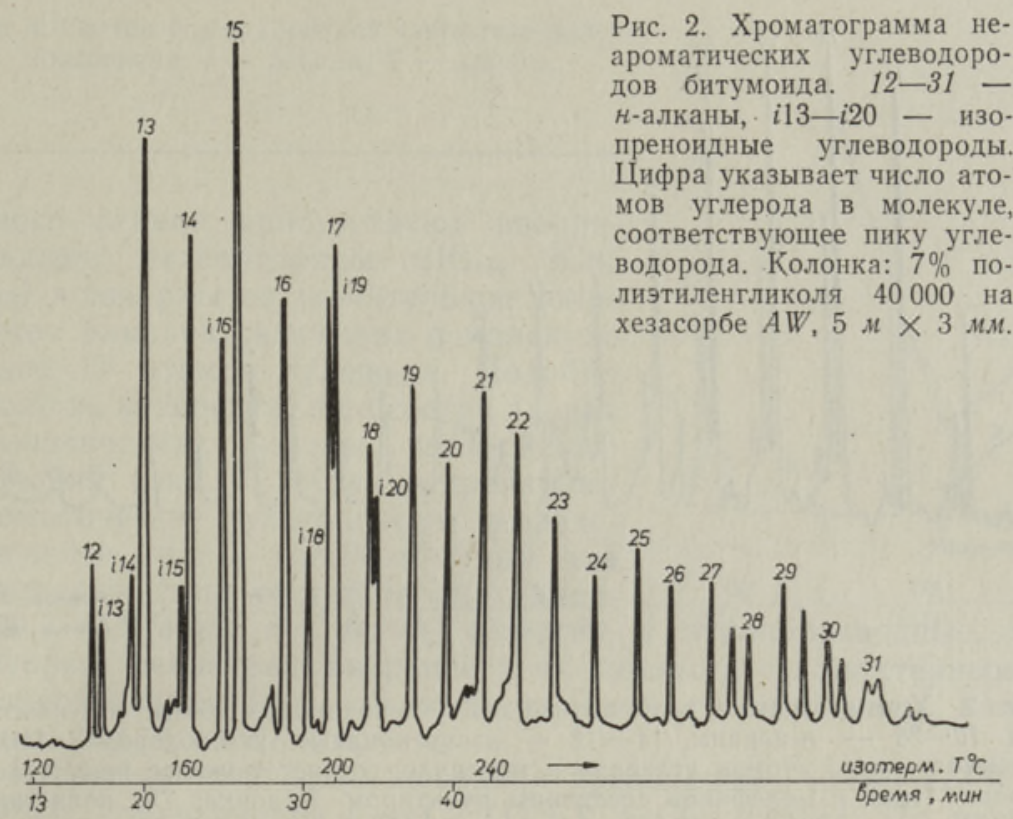

газохроматографически на аппіарате Хром-4) осуществлялось методом тонкослойной хроматографии по методике [4]. Инфракрасные спектры снимали на приборе UR-10.

Суммарный выход битумоида составил $0,7 \%$ на породу $(3,6 \%$ на органическое вещество), состав битумонда (вес. \%): асфальтены 54,2 ; смолы 36,3 ; масла 9,5 ; отношение битумонд $A$ : битумоид $C$ равно 0,95 . Выход продуктов полукоксования на породу (вес. \%): смола 6,2 (36,1 на кероген); полукокс 86,9; вода, газ и потери 6,9. Инфракрасные спектры битумоида и смол полукоксования показаны на рис. 1. Элементный состав битумоида и смолы из дебитуминированного сланца и групповой химический состав их хроматографируемой части приведены в таблице, где для сравнения имеются также соответствующие данные для кукерсита и диктионемового сланца.

По величине отношения битумоид $A$ : битумоид $C$ растворимая часть органическото вещества тетрасписового сланца имеет относительно кислый характер, по групповому составу данный сланец относится к битумоидам смолисто-асфальтенового типа. Хотя по содержанию в органическом веществе сланца битумоид находится на границе автохтонных и аллохтонных битумоидов [5], высокое содержание в нем гетероэлементов * и низкое масел, в том числе углеводородов, является признаком его автохтонной природы (см. таблицу). Отсутствие в исследовавшемся сланце следов миграции углеводородов, равно как и инфракрасный спектр битумоида (рис. 1), в котором имеются отсутствующие в спектрах явно вторичных битумоидов полосы 1740,1170 и $720 \mathrm{~cm}^{-1}\left[{ }^{9}\right]$ при сильной двойной полосе поглощения $1720-1740 \mathrm{~cm}^{-1}$ (карбонильные группы), также свидетельствует о сингенетичности битумонда (рис. 1).

Распределение $\boldsymbol{H}$-алканов в битумоиде тетрасписового сланца по длине цепи (рис. 2), характеризующееся наличием концентрационного максимума в области $\mathrm{C}_{13}-\mathrm{C}_{17}$ при ярко выраженном преобладании гомологов

* Некоторое обогащение гетероэлементами может иметь место в процессе пиритообразования. 


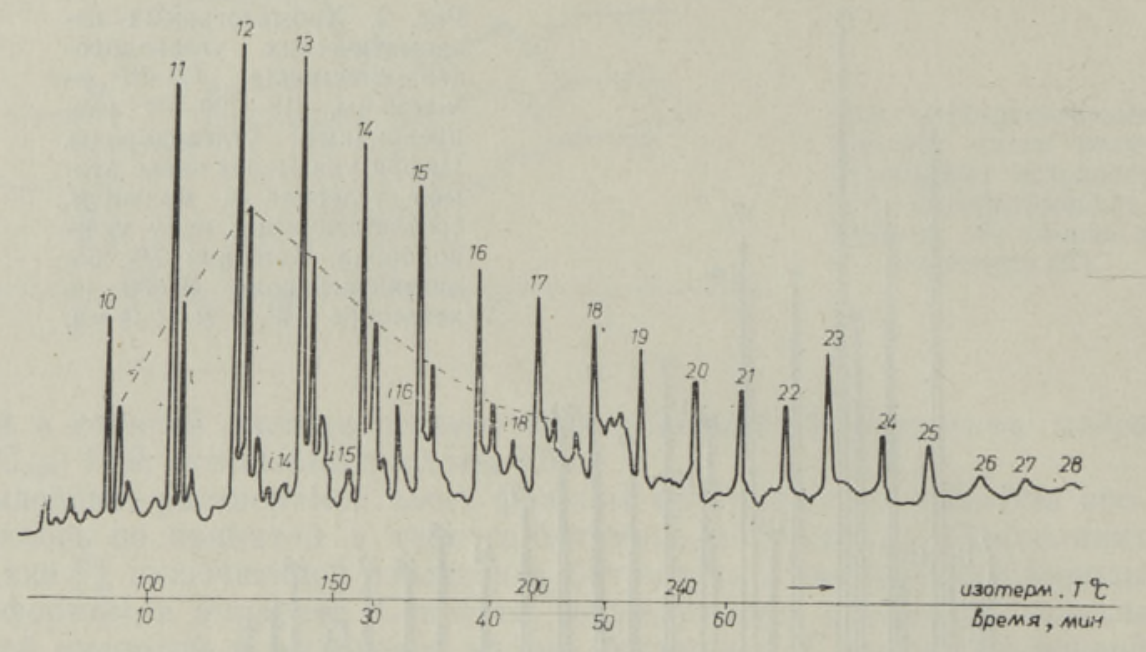

Рис. 3. Хроматограмма неароматических углеводородов смолы полукоксования. $10-28$ - н-алканы, $i 14-i 18$ - изопреноидные углеводороды. Цифра указывает число атомов углерода в молекуле, соответствующее пику углеводорода. Пики н-1-олефинов соединены пунктиром. Колонка: $7 \%$ полиэтиленгликоля 40000 на хезасорбе $A W, 5 \mathrm{M} \times 3 \mathrm{~m}$.

с нечетным числом атомов углерода в цепи, по имеющимся данным, явление довольно редкое. Подобное распределение н-алканов наблюдается также в девонских горючих сланцах Белоруссии, триасовых отложениях Северной Болгарии [10] и нижнеэоценовых сланцах Узбекистана [1']. Битумоид исследовавшегося сланца содержит также значительное количество изопреноидных углеводородов ( $48 \%$ от количества $H$-алканов в интервале $\mathrm{C}_{12}-\mathrm{C}_{20}$ ), для которых, как и для большей части осадочных пород и нефтей $\left[{ }^{12}\right]$, характерно преобладание пристана $\left(i \mathrm{C}_{19}\right)$ над фитаном $\left(i \mathrm{C}_{20}\right)$. Наряду с $i \mathrm{C}_{19}$ и $i \mathrm{C}_{20}$, в битумоиде в близких концентрациях содержатся низшие изопреноиды $\left(i \mathrm{C}_{13}-i \mathrm{C}_{16}, i \mathrm{C}_{18}\right)$ - продукты более глубокой деградации фитольной цепи хлорофилла.

В отношении распределения $H$-алканов по длине цепи, количества и состава изопреноидных углеводородов битумоид тетрасписового сланца занимает промежуточное положение между кукерситом и диктионемовым аргиллитом, тяготея к последнему (рис. 2).

По выходу смолы полукоксования на кероген $(36,1 \%)$, элементному и групповому составу смолы (таблица) сланец вормсиского горизонта также располагается между диктионемовым сланцем и кукерситом.

Судя по инфракрасным спектрам смол полукоксования тетрасписового сланца (рис. 1), в них, наряду с алифатическими, содержатся также ароматические структуры $\left(700-900,1610 \mathrm{~cm}^{-1}\right)$, имеющие до $2-3$ алкильных заместителей (поглощение в области $860-900 \mathrm{~cm}^{-1}$ слабое), по сравнению с битумоидом, содержание карбонильных групп $\left(1710 \mathrm{~cm}^{-1}\right)$ значительно ниже.

Газохроматографический анализ позволил охарактеризовать состав смолы несколько подробнее. На рис. 3 приведена хроматограмма алифатических углеводородов смолы. Для $H$-алканов, имеющих конщентрационный максимум в области $\mathrm{C}_{11}-\mathrm{C}_{13}$, свойственно относительно плавное уменьшение концентрации по мере увеличения длины цепи со слабым преобладанием гомологов с нечетным числом атомов углерода в молекуле. В отличие от смолы полукоксования кукерсита, в смоле тетраспи- 
Рис. 4. Состав углеводородной части газа полукоксования. 1 - алканы, 2 - алкены.

сового сланца присутствуют изопреноидные углеводороды $\left(i \mathrm{C}_{15}, \quad i \mathrm{C}_{16}\right.$, $i \mathrm{C}_{18}$ ) и содержится значительное количество алканов, имеющих в молекуле более 17 атомов углерода. Подобно смоле из кукерсита, в ее состав входят алифатические кетоны нормального строения (рис. 3). Конденсированные ароматические углеводороды исследовавшейся смолы имеют обычный для

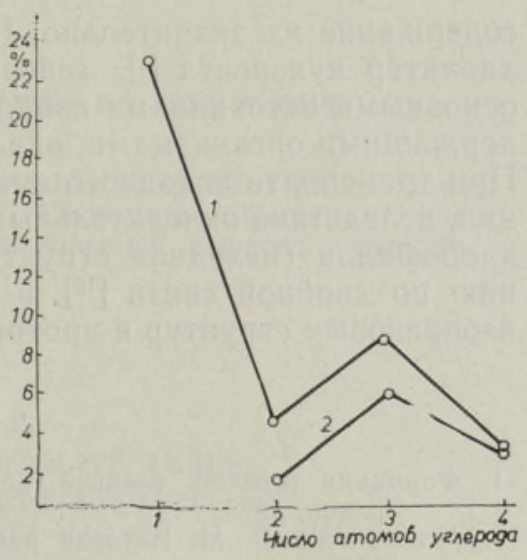
сланцевых смол состав: в них содержатся нафталин, его метил-, диметил- и этилпроизводные, аценафтен, флуорен, фенантрен, антрацен и их гомологи с характерным для смол полукоксования большей части сланцев соотношением концентраций отдельных компонентов.

В составе газа полукоксования преобладают метан $(23 \%)$, водород $(20 \%)$, углеводороды $\mathrm{C}_{2}-\mathrm{C}_{4}(17 \%)$ и $\mathrm{CO}_{2}(13 \%)$. По насыщенности углеводородной части газа (отношение алканы: алкены $=1: 5$ ), состав которой приведен на рис. 4, тетрасписовый сланец занимает промежуточное положение между малопревращенными (кукерсит, припятский сланец Белорусии) и претерпевшими заметное преобразование (доманиковый и нижнеэоценовые узбекские) сланцами.

В целом, по составу битумоида и продуктов разложения керогена тетрасписовый сланец находится между двумя другими сланцами Эстонской ССР - кукерситом и диктионемовым аргиллитом. Близок к нему также кембрийский сланец Якутии [13].

Заметную роль в формировании органического вещества тетрасписового сланца сыграла липидная фракция водорослей, в частности, жирные кислоты. На это указывает высокое содержание в битумоиде и смоле кислородсодержащих функциональных групп в сочетании с наличием в них алифатических углеводородов с длинной цепью и преобладанием нечетных гомологов. Присутствие в сланце углеродных цепей длиннее $\mathrm{C}_{17}$, не характерных для первичной морской биопродукции, свидетельствует в пользу участия бактерий в керогенообразовании, посколькv вклад наземной растительности (другого источника цепей выше $\mathrm{C}_{17}$ ) не мог быть существенным в силу геологического возраста сланца.

Учитывая сингенетичность и низкую степень превращенности битумоида сланца и незначительное погружение залежи в геологическом пласте, сланец вормсиского горизонта не мог быть источником нефтеподобных флюидов.

Несоответствие между составом алифатических цепей битумоида и нерастворимой частью органического вещества тетрасписового сланща, характерное для ряда сланцев, отмечалось также в случае современных осадков [14]. Поэтому указанное явление отражает, в основном, не действие катагенетических факторов, а различную степень и направленность биологического преобразования отдельных частей органического вещества осадка до его литификации.

Интересно, что в кукерсите, по геологическому возрасту находящемся между диктионемовым и тетрасписовым сланцами, практически отсутствуют изопреноидные структуры, тогда как в других двух сланцах 
содержание их значительно. Причинами этого могут быть аллохтонный характер кукерсита [ ['], генерация первичной биомассы, обогащенной основными источниками изопреноидных углеводородов - хлорофиллсодержащими организмами, вдали от места формирования залежи сланца. При транспорте исходного органического вещества на место седиментации, вследствие окислительных условий в водоеме $\left[{ }^{15}\right]$, фитольная группа хлорофилла (исходная структура изопреноидов) подверглась расцеплению по двойной связи [16], в результате этого процесса концентрация изопреновых структур в протокерогене понизилась.

\section{ЛИ Т Е Р А Т У Р А}

1. Формации горючих сланцев. (Методы изучения и генетическая классификация). Таллин, 1973.

2. М янниль Р. М. История развития Балтийского бассейна в ордовике. Таллин, 1960.

3. Руководство по анализу битумов и рассеянного органического вещества горных пород. Л., 1966.

4. Klesment, I. Application of chromatographic methods in biogeochemical investigations. - J. Chromatogr., 1974, v. 91, N 2, p. 705-713.

5. Н е руч е в С. Г. Нефтепроизводящие свиты и миграция нефти. Л., 1962.

6. У ров К. Э. Термическая деструкция сланца-кукерсита в вакууме. - Химия тв. топлива, 1976, № 5, с. 33-38.

7. Клесмент И. Р., Р иккен Ю. Т., Уров К. Э. Особенности органического вещества диктионемовых сланцев. - Горючие сланцы, 1976, № 6, с. 20-26.

8. С и й рде А. К. Характеристика смолы полукоксования диктионемового сланца. Тр. Таллинск. политехн. ин-та, серия А, 1958, № 97, с. 91-103.

9. Не руче в С. Г. Нефтепроизводящие свиты и миграция нефти. Л., 1969.

10. Vuchev, V. T., Howells, W. G., Burlingame, A. L. The presence and geochemical significance of organic matter extractable from Jurassic and Triassic sediments of Northern Bulgaria. - In: Advances of organic geochemistry. Oxford, 1971 , p. $365-386$.

11. Уров К. Э., Л истрем А. И., Ав а зм атов Х. Б. О составе битумоидов и нерастворимой части органического вещества сузакских горючих сланцев Западного Узбекистана. - В кн.: Тезисы докладов V Всесоюзного семинара «Органическое вещество в современных и ископаемых осадках». М., 1976, c. 187.

12. Солодков В. К., Д рагунская В. С., К амьянов В. Ф. Изопреноидные углеводороды и генезис нефти. - Изв. АН Туркм. ССР, Сер. физ.-техн., хим. и геол., 1975 , № 3 , с. $48-54$.

13. Клесмент И. Р., Риккен Ю. Т., Уров К. Э., Эйзен О. Г. Характеристика органического вешества оленекского горючего сланца. - Изв. АН ЭССР, Хим. Геол., 1977 , т. 26 , № 4, с. $257-263$.

14. Is hiw at a ri, R., Ishiwat a ri, M., Rohrback, B. G., Kaplan, I. R. Thermal alteration experiments on organic matter from recent marine sediments in relation to petroleum genesis. - Geochim. et cosmochim. acta, 1977, v. 41, N 6, p. 815-828.

15. Р а удсепп Х. Т. О генезисе эстонского горючего сланца кукерсита. - В кн.: Генезис твердых горючих ископаемых. М., 1959, с. 69-76.

16. Клесмен т И. Р. Геохимическая история изопреноидов и порфиринов в седиментах. - В кн.: Тезисы докладов Всесоюзной конференции по химии и геохимии порфиринов. Душанбе, 1977, с. 57.

Ннститут химии

Академии наук Эстонской ССР

Поступила в редакщию

12/XI 1977 
A. JAANUS, K. UROV, I. KLESMENT

\section{LOUUNA-EESTI VORMSI LADEME GRAPTOLIITKILDA ISELOOMUSTUS}

Artiklis on gaasikromatograafilise uuringu põhjal kirjeldatud Lõuna-Eesti vormsi lademe graptoliite Tetraspis sisaldava kilda orgaanilist ainet. Elementaar-, rühmalise ja individuaalse koostise poolest on see diktüoneemakilda ja kukersiidi kerogeeni vahepealne. Tema lähtematerjaliks on olnud vetikad ja bakterid.

\section{A. JAANUS, K. UROV, I. KLESMENT}

\section{CHARACTERISTICS OF THE GRAPTOLITE SHALE OF VORMSI STAGE FROM SOUTH ESTONIA}

Organic matter of the shale from Vormsi Stage in South Estonia, containing Tetraspis graptolites, was investigated by chromatographic methods. The elemental, group and individual composition of organic matter of the shale lies between those of dictyonema shale and kukersite. In forming the organic matter of the shale, algae and bacteria have taken part. 